\title{
The Role of Active carbons in the Ecology of extraction, transportation and processing of petroleum
}

\author{
Mukhin Viktor Mikhailovich ${ }^{1 \star}$ and Korolev Nikolay Vladimirovich ${ }^{2}$ \\ 'AO "ESPE" Neorganika", 4, K. Marx Street, Elektrostal, Moscow Region, Russian Federation, Russia \\ ${ }^{2}$ Ph.D. in Chemistry, Adviser to Director General for assets and strategic development TopProm JSC, prospect Ermakova, 9-A \\ Business center CITY, Novokuznetsk, Kemerovo region, Russia
}

\section{Article Info}

\section{*Corresponding author: \\ Mukhin Viktor Mikhailovich \\ Doctor of Technical Sciences, Professor \\ Head of the laboratory of active carbons \\ elastic sorbents and catalysts of $A O$ \\ "ESPE" Neorganika, 4, K, Marx Street \\ Elektrostal Moscow Region, Russian \\ Federation, Russia \\ Tel: (+7) 9166519757 \\ E-mail: VictorMukhin@yandex.ru}

Received: October 1, 2018

Accepted: October 29, 2018

Published: November 5, 2018

Citation: Mukhin VM, Vladimirovich KN. The Role of Active carbons in the Ecology of extraction, transportation and processing of petroleum. Int J Petrochem Res. 2018; 2(3): 189-193

doi: 10.18689/ijpr-1000134

Copyright: ( $\odot 2018$ The Author(s). This work is licensed under a Creative Commons Attribution 4.0 International License, which permits unrestricted use, distribution, and reproduction in any medium, provided the original work is properly cited.

Published by Madridge Publishers

\begin{abstract}
The article presents the results of studies performed in the period 1991-2016 on the protection of the environment from man-made impact by means of carbon adsorption technologies. However, they were published in publications far from the oil and gas complex and were not known to a wide range of environmental specialists in this industry. There is shown the use of active carbons (carbon adsorbents) for solving environmental problems in the oil industry.
\end{abstract}

Keywords: Active carbons, ecology, oil and oil products, environmental protection, carbon adsorption technologies.

\section{Introduction}

Currently, the use of adsorption technologies based on active carbons (AC) is developing rapidly throughout the world, which is largely due to three factors: first, they ensure the production of high purity products in a number of industries; secondly, they promote the introduction of high-intensity technologies; thirdly, what is especially important, they allow the creation of new products and new areas of their application. They help to solve a wide range of issues in gas production and gas processing, new energy (super capacitors), gold mining and processing of non-ferrous metals, medicine and health, drinking water and wastewater treatment, defense of the country and space exploration, in short, in all spheres of the Russian economy [1].

At the same time, AC plays a special, even a decisive role in protecting the environment from harmful emissions and solving a wide range of environmental safety issues [2].

During extraction, transportation and processing of oil, there may be cases when liquid or gaseous hydrocarbons enter the biosphere and environmental protection measures are required. And we have special difficulties here: liquid hydrocarbons are fairly persistent, and vapor and gaseous hydrocarbons are extremely volatile.

Due to their physical and chemical properties, active carbons (carbon adsorbents) can be effectively used to solve environmental problems in this field.

Active carbons (activated carbons) are highly porous solids obtained on the basis of carbon-containing raw materials, having a developed internal surface from hundreds to $2500 \mathrm{~m}^{2} / \mathrm{g}$ and having high absorption characteristics for impurities located in cleaned environments (air, gases, water, liquids, soil).

Below in table 1, the main environmental trends for the application of $A C$ in the oil industry are presented, both already implemented in practice and having a good prospect for implementation. 
Table 1. Ecological directions of application of active carbons in oil production, transportation and processing

\begin{tabular}{|c|c|c|}
\hline & $\begin{array}{c}\text { Stages of oil production and } \\
\text { processing }\end{array}$ & $\begin{array}{l}\text { Directions of application of active } \\
\text { carbons (AC) }\end{array}$ \\
\hline 1. & $\begin{array}{l}\text { The accident at the drilling site, } \\
\text { associated with oil ingress into the } \\
\text { soil of farmland }\end{array}$ & $\begin{array}{l}\text { Detoxification of soils. AC are the } \\
\text { carriers of strains - oil destructors. }\end{array}$ \\
\hline 2. & $\begin{array}{l}\text { The accident at the drilling site, } \\
\text { associated with the oil ingress into } \\
\text { sources of water supply. }\end{array}$ & $\begin{array}{l}\text { Connecting adsorbers or filters with } \\
\text { AC. }\end{array}$ \\
\hline 3. & $\begin{array}{l}\text { Transportation of oil and } \\
\text { protection of pipelines from } \\
\text { damage by weed vegetation due } \\
\text { to herbicides. }\end{array}$ & $\begin{array}{l}\text { Creation of protective strips with } \mathrm{AC} \\
\text { to prevent the migration of herbicides. }\end{array}$ \\
\hline 4. & Pouring oil into tankers. & Recovery of hydrocarbon vapor. \\
\hline 5. & $\begin{array}{l}\text { Recovery of solvents vapor in } \\
\text { petrochemical industries. }\end{array}$ & Capture and return to production. \\
\hline 6. & $\begin{array}{l}\text { Sanitary purification of air from } \\
\text { products of petrochemical industries. }\end{array}$ & Protection of the atmosphere. \\
\hline & $\begin{array}{l}\text { Wastewater treatment at refineries } \\
\text { and petrochemical enterprises. }\end{array}$ & Protection of the hydrosphere. \\
\hline 8. & $\begin{array}{l}\text { Refining of liquid products of } \\
\text { petrochemistry and oil refining. }\end{array}$ & $\begin{array}{l}\text { Reducing the volume of solid and liquid } \\
\text { wastes. Protection of the lithosphere. }\end{array}$ \\
\hline & $\begin{array}{l}\text { Application of filtering gas masks } \\
\text { and respirators. }\end{array}$ & $\begin{array}{l}\text { Protection of personnel against } \\
\text { exposure of harmful gases and vapors. }\end{array}$ \\
\hline & $\begin{array}{l}\text { Other technologies of oil refining } \\
\text { and receipt of petrochemical products. }\end{array}$ & $\begin{array}{l}\text { Increasing the efficiency of production } \\
\text { and its profitability. }\end{array}$ \\
\hline
\end{tabular}

Let's consider these ecological directions of AC application in extraction, transportation and processing of oil in detail.

Accident on the drilling site, associated with the ingress of oil on the soil of farmland. This is unacceptable, especially in such regions as the North Caucasus and the Volga region. Mechanical methods of spill response can reduce the dose of contamination to $10 \mathrm{MPC}$, but not more. Achievement of soil cleaning up to the norm of MPC is possible with the use of active carbons with the technology "Agrosorb".

The essence of the method of carbon sorption detoxification of soils is to introduce AC in doses of 50-100 $\mathrm{kg} / \mathrm{ha}$ with subsequent filling them to a depth of $10-15 \mathrm{~cm}$ into the soil with the use of AC agricultural machinery. In this case, toxic hydrocarbons in the soil are fixed on the porous structure of the $A C$, they are deprived of the possibility of migration with soil solutions and the introduction into the root system of plants. This allows increasing yields on contaminated soils and preventing accumulation of toxins in crop production. So the experiments carried out in the Institute of Phytopathology (Golitsino, Moscow region) on soils contaminated with different types of pesticides (chlorsulfuron, terbacil, picloram, simazin, etc.) showed that the use of $A C$ allowed increasing yields on soils contaminated with pesticide residues by $20-100 \%$ and completely eliminate their accumulation in fruits and grains [3].

The newest direction is the sorption-biological remediation of soils, developed by the AO

"ESPE" Neorganika "jointly with the Institute of PhysicalChemical and Biological Problems of Soil Science of the Russian Academy of Sciences (Puschino, Moscow region). This direction is associated with the method of soil purification, based on the use of small doses of adsorbent (1-5\% of the mass of soil), which is introduced into the soil together with specially grown microbial strains - destructors of pesticides [4].
These methods, apparently, can be adapted to the cleaning of soils contaminated with various organic chemicals, as well as oil and petroleum products.

The volume of $A C$ consumption in this sphere can reach 100 tons per year.

The accident at the drilling site, connected with the ingress of oil into sources of water supply. In this case, at the water supply stations of large cities, it is possible to apply emergency backfill to sand filters of granulated active carbon of the brand "Hydrosorb", which together with increasing the oxidizer (chlorine or ozone) dose will promptly improve the water quality (this method was used at the water canal of Khabarovsk, when toxic substances from the Chinese oil refinery hit the Amur River).

Undoubtedly, residents of small settlements and rural settlements in the oil production areas should be provided with household filters for additional treatment of drinking water of the type "Barrier" or "Rodnik-8H", and in case of oil entering the wells of rural residents - with field filters for additional treatment of water "Tourist-2M" [5].

Strategically perspective protection of the hydrosphere in oil producing areas close to large rivers (Pechora, Ob, etc.) should be the development and construction of water filtration tanks filled with $A C$ equal to the surface runoff of the river to a depth of $2-5 \mathrm{~cm}$. After oil gathering with booms its remains will still be on the surface of the water and pumping out the upper layer of water through the filter tanks with AC will minimize the damage to the biosphere of rivers and lakes. Nothing is impossible. During a business trip in 2002 to the Water Technology Center of Germany (Stuttgart), Professor Kuhn (Head of the Center) explained that in the area of old chemical landfills in the direction of the drain to the Rhine, filtering barriers with active carbon with the depth up to $50 \mathrm{~m}$ were made, in which waste AC is replaced with fresh one. Today, even the trout are found in the Rhine River near Koblenz.

The volume of consumption of $A C$ in this sphere will be 500 tons per year.

Transportation of oil and protection of pipelines from damage by weed vegetation due to herbicides. It is known that one of the reasons for the rupture of buried oil pipelines is damage by the root system of plants. To prevent this, the surface of oil pipeline routes is treated with herbicides (such as Arcel, Oust, etc.). However, this pipeline protection technology has also negative consequences, due to the fact that herbicides migrate with rain and groundwater up to $200 \mathrm{~m}$ from the pipeline route. This leads to the defeat of trees in the forest zone, and in the zone of rural farms to the oppression of crops. Oil transportation companies pay fines for violating the environmental situation. The use of the Herbosorbent technology developed by the AllRussia Institute of Phytopathology (Golitsino, Moscow Region) and AO "ESPE "Neorganika" (Elektrostal, Moscow Region) allows, on the one hand, to fix herbicides on the oil pipeline route, preventing them from entering adjacent territories of the lithosphere, and, on the other hand, provides its prolonged action for several years, reducing the multiplicity of treatments. The economic and environmental effect in both cases is quite 
significant. The volume of $A C$ consumption in this sphere will make 600 tons per year.

Pouring oil into tankers. When oil is poured into tankers, light hydrocarbons $\left(C_{3}-C_{5}\right)$ often evaporate, which leads to air pollution. In the company Transneft-Kozmino OOO, the vapors of hydrocarbons are sucked off and fed to a recovery unit, where they are recycled. Adsorbers are supplied with active carbons of the brand CGF4 or CGF4 Pluse produced by CarboTech AC GmlH (Germany). However, this AC has a low total porosity, which significantly reduces the removal of solvent from the recovery unit.

Undoubtedly, there are wide opportunities for optimizing the porous structure of such AC and increasing its efficiency, as well as organizing its production in Russia.

On the other hand, after working off its resource, active carbon from recovery units (150 tons per year) was exported to a landfill and replaced with fresh one, which led to contamination of the lithosphere. However, it has been shown that it is rational to carry out its reactivation and re-use for the same purposes with the technology developed by AO "ESPE "Neorganika". During reactivation, it is necessary to optimize such basic parameters as temperature, consumption of oxidizing agent and phase contact time, and also to take into account that the temperature should be within $800-850{ }^{\circ} \mathrm{C}$, since when it decreases the rate of interaction of the oxidizing gas with the micro porous blocking material becomes small, when the temperature increases, intensive burning out of the micro porous walls and an increase in the surface carbon burning are inevitable.

The work on the industrial reactivation of waste $A C$ is described in detail in the monograph by V.M. Mukhin and V.N. Klushin [2]. It is shown (see table 2) on the example of reactivation of $A R-B$ spent carbon, that the adsorption capacity of reactivated $A C$ is increased due to the additional development of micro pores.

Table 2. Characteristics of reactivated and industrial active carbon

\begin{tabular}{|l|l|l|l|l|}
\hline $\begin{array}{l}\text { Mark of active } \\
\text { carbon }\end{array}$ & $\begin{array}{l}\text { Bulk } \\
\text { density, } \\
\mathbf{g} / \mathbf{d m}\end{array}$ & $\begin{array}{l}\text { Abrasion } \\
\text { Resistance, } \\
\%\end{array}$ & $\begin{array}{l}\text { Total } \\
\text { porosity, } \\
\mathrm{cm}^{3} / \mathbf{g}\end{array}$ & $\begin{array}{l}\text { Adsorption capacity } \\
\text { for toluene }\left(\mathbf{c}_{0}=10\right. \\
\left.\mathbf{m g} / \mathbf{d m}^{3}\right), \mathbf{g} / \mathbf{d m}^{3}\end{array}$ \\
\hline $\begin{array}{l}\text { AR-R } \\
\text { (reactivated) }\end{array}$ & $480-500$ & $70-80$ & $0,8-0,9$ & $140-164$ \\
\hline AR-V & 680 & 75 & $0,52-0,58$ & 110 \\
\hline AR-B & 580 & 70 & $0,6-0,65$ & 135 \\
\hline AR-A & 550 & 65 & $0,7-0,76$ & 145 \\
\hline AR-V \\
(waste) & 620 & 76 & 0,68 & 80 \\
\hline
\end{tabular}

The strength of active carbon during reactivation is practically not reduced, and the yield of the finished product is $92-95 \%$, which makes it possible to use this AC up to 10 times. It is easy to calculate that real savings in this case in one port of oil pouring can reach 315 million rubles.

The volume of AC consumption in this sphere will be 800 tons per year.

Recovery of solvent vapors in petrochemical plants. The losses and solvent emissions in the early 1990s were estimated at 600-800 thousand tons per year. Taking into account that the dynamics of the development of petrochemical industry in the Russian Federation did not decrease [6], the emissions of solvents remained at the same level. In most cases, the concentration of solvent vapors in the off-gas is low (several g per $1 \mathrm{~m}^{3}$ ), which in most cases determines the exclusive choice of the adsorption method for their recovery using active carbons.

The unique technology of recuperative spherical (diameter 0.5-3.0 mm) carbon sorbent from synthetic raw materials furfural has been developed in AO "ESPE" Neorganika" by Dr. Ch. Sc. V. Guryanov (trademark active carbon FAS) [7]. It is produced by liquid molding of furfural copolymers and some resins (epoxy, AC, etc.), added in an amount of 3-7 \% by weight, followed by thermosetting; carbonization and activation are carried out on rotating electric furnaces with a retort diameter of $325 \mathrm{~mm}$.

The uniqueness of the active carbon FAS (Furfural Active Sorbent) is that this carbon is "Ceiling" (you can jump to the ceiling, but you cannot go higher): its strength in accordance with GOST $16188-70$ is $100 \%$, which corresponds to the crushing strength of $7500 \mathrm{~kg} / \mathrm{cm}^{2}$, it's the porous structure is $100 \%$ composed of a volume $\left(0,8 \mathrm{~cm}^{3} / \mathrm{g}\right)$ of sorptive microand mesopores only, and the ash content in it is close to zero, i.e. it has $100 \%$ purity. It is known that ash is the main enemy of recuperative $A C$, especially used in the recovery of organchlorine solvents, since it leads to the hydrolysis of a solvent and the destruction of carbon.

To determine the regularities of adsorption of active carbon FAS by chlororganic compounds ( $\mathrm{CHO}$ ) vapors, methylene chloride (MC) and dichloroethane (DCE) are used as fairly common solvents. A significant difference in their physicochemical properties provides a reliable estimate of the feasibility and effectiveness of using active carbon FAS for the recovery of the entire range of $\mathrm{CHO}$. The studies were carried out at the bench laboratory installation of the Dzerzhinsky branch of NIIOGAZ. (Tables 3 and 4) show the results of experiments performed in the adsorption-regeneration cycle of adsorbents on active carbon FAS (TU 6-16-28-1578-94) and AR-B (GOST 8703-74) (the latter is widely used in recuperation technology) under the following conditions:

Adsorption: The linear velocity of PVA is $0.3 \mathrm{~m} / \mathrm{s}$, the relative humidity of PVA is $18 \%$, the temperature of PVA is $25^{\circ} \mathrm{C}$, the length of the carbon layer is $15 \mathrm{~cm}$.

Desorption: Temperature is $110{ }^{\circ} \mathrm{C}$, steam consumption is $0.75 \mathrm{~g} / \mathrm{min}$, desorption time is $60 \mathrm{~min}$.

As it follows from the data of tables 3 and 4, the adsorption capacity of active carbon FAS is approximately two times higher than that of $A R-V$ carbon.

Table 3. Results of experiments on the adsorption of active carbon FAS and active carbon AR-V vapors of dichloroethane

\begin{tabular}{|c|c|c|c|c|}
\hline \multirow{2}{*}{$\begin{array}{c}\text { Mass } \\
\text { concentration } \\
\text { in the gas } \\
\text { phase, } \mathbf{g}, \mathbf{g} / \mathbf{m}^{3}\end{array}$} & $\begin{array}{c}\text { Length of the } \\
\text { working layer } \\
\text { on active carbon } \\
\text { FAS, } 10^{2} \cdot \mathbf{M}\end{array}$ & \multicolumn{2}{|c|}{$\begin{array}{c}\text { Realized activity of active } \\
\text { carbon FAS, \% of mass }\end{array}$} & $\begin{array}{c}\text { Implemented } \\
\text { activity of active } \\
\text { carbon AR-V, } \\
\% \text { of mass }\end{array}$ \\
\hline 1,5 & 4,3 & 29,6 & 34,5 & 16,1 \\
\hline 4,0 & 5,3 & 39,1 & 41,8 & 18,8 \\
\hline 9,1 & 5,9 & 47,5 & 48,3 & 20,3 \\
\hline 29,0 & 10,2 & 51,9 & 56,8 & 21,1 \\
\hline 32,2 & 10,6 & 54,5 & 57,5 & 21,3 \\
\hline
\end{tabular}


Table 4. Results of experiments on the adsorption of active carbon FAS and active carbon AR-V vapors of methylene chloride

\begin{tabular}{|c|c|c|c|c|}
\hline \multirow{2}{*}{$\begin{array}{c}\text { Mass } \\
\text { concentration } \\
\text { in gas } \\
\text { phase, } \mathrm{g} / \mathrm{m}^{3}\end{array}$} & \multirow{2}{*}{\begin{tabular}{|c|} 
Length of the \\
working layer \\
on active carbon \\
FAS $10^{2} \cdot \mathrm{m}$
\end{tabular}} & \multicolumn{2}{|c|}{$\begin{array}{c}\text { Realized activity of active } \\
\text { carbon } \\
\text { FAS, mass } \%\end{array}$} & \multirow{2}{*}{$\begin{array}{c}\text { Realized activity } \\
\text { of active carbon } \\
\text { AR-V } \\
\% \text { of mass }\end{array}$} \\
\hline & & experience & calculation & \\
\hline 1,5 & 7,9 & 12,9 & 11,6 & 8,2 \\
\hline 1,7 & 8,5 & 13,1 & 12,1 & 8,6 \\
\hline 6,0 & 8,8 & 23,0 & 19,0 & 13,2 \\
\hline 6,8 & 8,8 & 22,7 & 20,6 & 13,7 \\
\hline 15,3 & 9,4 & 34,6 & 27,0 & 17,1 \\
\hline 36,5 & 11,9 & 42,6 & 34,7 & 21,0 \\
\hline
\end{tabular}

During the study it was also found that the initial moisture of the adsorbent in the range of $0-30 \%$ by weight and relative humidity of PVA within 0-80\% slightly reduce the equilibrium capacity of active carbon FAS, while in the case of AR-V it decreases by 1,8 times in DCE pairs and by 2,7 times in MC pairs.

In systems with active carbon FAS, the degree of hydrolysis of DCE is 5-10 times lower than in systems containing AR-V carbon. In control experiments in the "water + st.12X18H10T + DCE" system at temperature of $100{ }^{\circ} \mathrm{C}$ and a holding time of 5-30 hours, the degree of decomposition of DCE was from 0.041 to $0,13 \%$.

Important data on the strength of active carbon FAS during its operation in a fluidized bed were obtained in 1995 at a gas flow rate of $0.9-1.1 \mathrm{~m} / \mathrm{s}$ performed at the NIIOGAZ test rig (Dzerzhinsk, Nizhny Novgorod region) in 1995. The loss of weight of active carbon FAS after 700 hours of continuous operation amounted to about $2 \%$ (the replaceable filters installed behind the adsorber did not contain any visually detectable carbon dust after 2 hours of operation), while the losses of active carbon AR-V reached $50 \%$ in 484 hours .

Thus, the possibility and rationality of the use of active carbon FAS grade active carbon in the processes for cleaning off the exhaust gases from the $\mathrm{CHO}$ and their recovery are established. The advantages of active carbon FAS in these areas in comparison with active carbon of type AR are a higher capacity for $\mathrm{CHO}$ vapors, a relatively small length of the working layer, much less influence of humidity of PVA and adsorbent on adsorption of $\mathrm{CHO}$, low catalytic activity in the process of hydrolysis of $\mathrm{CHO}$ and high abrasion resistance, which allows its use in installations with boiling and moving layers. This also determines it's prospectively as a catalyst carrier in the processing of hydrocarbon raw materials. Such work is now being carried out at OAO VNIIUS (Kazan).

At a conference on ecology in San Diego, California, in 2006, Professor Larry of Ohio State University in Cincinnati asked me: "Have you already started manufacturing the active carbon FAS?" I said, "Larry, we have a scientific conference and I talk about the properties of active carbon FAS. Why are you asking a question about its industrial production? "He turned to the audience and said:" If you started its production, we have nothing to do here, we all go broke".

Thus, the results of the study make it possible to justify the need for a rapid organization of industrial production of active carbon FAS in the volumes required for the Russian economy.
The volume of $A C$ consumption in this sphere will be 4000 tons per year.

Sanitary cleaning of air from petrochemical products. A wide range of technologies for sanitary carbon-sorption purification includes, in particular, processes for trapping ammonia, chlorine, carbon disulphide, sulfur dioxide, hydrogen sulfide, mercury, hydrocarbons, organic and organochlorine solvents of low concentration $\left(<1 \mathrm{~g} / \mathrm{m}^{3}\right)$ and is solved with the help of active carbons, catalysts and chemical absorbers on their basis. The processes of sanitary cleaning can be divided into the following main areas: desulfurization of gases, removal of radioactive gases and adsorption of harmful and foul-smelling substances.

These processes are described in the monograph of Professor Keltsev N.V [8] and the monograph of E. Bader and H. Kinle [9].

The volume of $A C$ consumption in this sphere will be 2000 tons per year.

Wastewater treatment at oil refining and petrochemical enterprises. Sewage is, perhaps, the most obvious, most visible damage to the environment, primarily to the hydrosphere (rivers, lakes, seas and even oceans). It is believed that in order to ensure the MPC of pollutants in discharged wastewater by diluting them, about $1 / 3$ of the world's fresh water supply is required. Therefore, since the early 1980 s this aspect of the protection of the biosphere has been paid special attention in our country.

Typically, it is most effective to use the sorption cleaning of low-concentrated by the target components effluents, when the required quality of the purified water is achieved by applying a minimum amount of sorbent. The economical nature of the sorption purification of wastewater is proved, in particular, by the results of a comparative assessment by American experts of the possibility of obtaining $500,000 \mathrm{~m}^{3}$ per day of clean water in the Southern California area using a seawater desalination plant with a nuclear reactor and through deep sorption purification of available sewage. It turned out that in the first case the cost of water is 1.8 times higher, and construction costs are 7.5 times higher [10].

In view of the foregoing, it should be considered that the work on the creation of circulating water cycles and closed water supply and sewerage systems, based on the purification and neutralization of sewage with the use of sorption, are most preferable and promising for oil refining and petrochemical enterprises.

The volume of $A C$ consumption in this sphere will be 4000 tons per year.

Refining of liquid petrochemical products and oil refining. In industries of this orientation, powder active carbons with a particle size of less than $100 \mu \mathrm{m}$ are usually used with their introduction into technological solutions in order to clarify the latter by adsorption of various organic impurities and the products of resinification in the pores of adsorbents.

It is very common to use active carbons to purify organic products, including those used for synthesis. So, in particular, the 
active carbon OU-A is used for the production of polyethylsiloxane fluids, lubricating oils and special products, active carbon AG-3 is used for the production of fluoropolymers, OU-A and BAU-A activated carbons are used for the production of glycerin, 4, active carbon OU-A is applied for purifying 4.4-diaminodiphenyl ether and also for cleaning glues and fumaric acid [2].

Specific here is the use of powdered active carbon grade OU-A in the production of plasticizers used to produce synthetic materials, including materials with a strong gloss. A certain amount of active carbon is added to the raw material already during the synthesis of the product; however, the main quantity goes to the clarification of the finished product. Such materials are the basis for high-quality toys, sports shoes and much more. The main production of plasticizers is concentrated in petrochemical plants in the cities of Surgut, Nizhnevartovsk, Kogalym and Angarsk, with the consumption by each one of 150-200 tons of OU-A active carbon.

The volume of consumption of $A C$ in this area will be 2000 tons per year.

The use of filter masks and respirators. Production of gas masks, respirators and collective protection equipment is impossible without high-quality active carbons and sorption materials based on them: catalysts and chemical absorbers. Effective functioning of many important industries in Russia is provided by this aspect of carbon-absorption technology. The entire system of protecting the population from manmade disasters is based on the use of individual filtering-type filter protection devices based on AC.

Modern means of protection of the filtering type are created on the basis of block sorption systems developed in AO "ESPE" Neorganika" (Electrostal, Moscow region) under the supervision of the Doctor of Technical Sciences, Professor V.F. Smirnov [2].

The volume of $\mathrm{AC}$ consumption in this area will make 500 tons per year.

Other technologies for oil refining and obtaining petrochemical products. The development of new technologies in these areas raises the task of synthesizing effective carbon adsorbents, and the market size and breadth of application of AC are truly inexhaustible.

Let's take a concrete example. TAIF-NK Company (Nizhnekamsk) realizes the process of tar processing into valuable petroleum products: naphtha, diesel fuel, hydro treated vacuum gas oil due to the absorption of asphalt compounds with active carbon. The volume of $A C$ consumption in this area will make 28000 tons per year.

The total volume of AC production in the world today is 1 million 250 thousand tons per year and is characterized by a steady growth of $5 \%$ per year. The maximum productivity for active carbons of 4 main enterprises of the USSR reached 40 thousand tons per year (1989). Currently, only 3.0 thousand tons per year are produced in the Russian Federation at the only remaining plant. About 25-30 thousand tons of $A C$ is imported peryear (USA, Holland, France, China, etc.). Speaking about the level of ecology and economy of the country, it is necessary to pay attention to the specific production of $A C$ that in the USA, Japan and Western Europe is at the level of $0.5 \mathrm{~kg} /$ person per year. In Russia, this indicator is now 0,02 $\mathrm{kg} /$ person in a year. Proceeding from the foregoing, our country needs to produce at least 70 thousand tons of active carbon per year (today 3 thousand tons is produced per year) for sustainable economic development and the creation of a high quality of life for the population [11,12].

\section{Conclusion}

Based on the foregoing, the petroleum and petrochemical industry of Russia requires about 14,500 tons per year of active carbons of various brands. This obviously represents about $20 \%$ of the total demand of our country in AC and almost $50 \%$ of the share of imported carbon adsorbents.

The concept of sustainable development in general cannot be realized on the territory of the Russian Federation without active carbons due to significant pollution of water, soil and agricultural products.

Thus, the speedy organization of new nuclear power plants in the Russian Federation on the basis of domestic active carbon raw materials (first of all, Kuzbass) will undoubtedly give a powerful impetus to the development of productive forces and to the effective protection of the environment, which fully fits into the concept of sustainable development and the creation of a high quality of life of people.

\section{References}

1. Mukhin VM, Tarasov AV, Klushin VN. Active carbons of Russia. Metallurgy. 2000; 352.

2. Mukhin VM, Klushin VN. Production and application of carbon sorbents. M. RCHTU after D.I. Mendeleev. 2012; 307.

3. Spiridonov YY, Mukhin VM, Voropaeva NL, Bogdanovich NI. Carbon and sorption detoxification of soils contaminated with residues of herbicides. Materials of International scientific-practical conference "Modern problems of herbology and soil improvement" RAN-FBGNU Institute of Phytopathology, 2016; 336-341.

4. Bakhaeva LP, Vasilieva GK, Surovtseva EG, Mukhin VM. Microbial degradation of 3, 4-dichloroaniline adsorbed by activated carbon. Microbiology. 2001; 70: 277-284. doi: 10.1023/A:1010495025794

5. Buchnev SI, Shelyapin IP, Kiselev EN, Mukhin VM. Filters for drinking water purification in the field conditions. RF Patent number No. 2077490, 1997.

6. Aminev SH. Journal of Chemical Industry. 2015; 82(1): 10-19.

7. Guryanov VV, Mukhin VM, Kurilkin AA. Developing Ash-Free HighStrength Spherical Carbon Catalyst Supports. Catalysis in Industry. 2013; 5(2): 156-163. doi: 10.1134/S2070050413020062

8. Keltsev NV. Fundamentals of adsorption technology. Chemistry. 1976; 511.

9. Kienle $\mathrm{H}$, Bader E. Aktivkonle und ihre industrielle anwendung. Stuttgard.: Ferdinand Enke Verlag Stuttgard, 1980; 215.

10. Smirnov AD. Sorption water treatment. Chemistry. 1982; 168.

11. Mukhin VM. Active carbons, elastic sorbents, catalysts, dryers and chemical absorbers based on them. edition, Ores and metals. 2003; 273.

12. Mukhin VM, Kurilkin AA, Leksyukova KV, et al. A position of active carbons in the ecology and economy, new technologies of their production. Sorption and chromatographic processes. 2016; 16(3): 346-353. 